\title{
The 70-Gene Signature as Prognostic Factor for Elderly Women with Hormone Receptor-Positive, HER2-Negative Breast Cancer
}

\author{
Steffi Hartmann ${ }^{a} \quad$ Bernd Gerber $^{a} \quad$ Dirk Elling $^{b} \quad$ Kristin Heintze $^{a} \quad$ Toralf Reimer $^{a}$ \\ aDepartment of Obstetrics and Gynecology, University of Rostock, Germany \\ ${ }^{b}$ Oskar-Ziethen-Krankenhaus, Department of Obstetrics and Gynecology, Berlin, Germany
}

\section{Keywords}

Breast cancer - 70-Gene prognosis signature .

Postmenopausal · Elderly · Prognostic factor

\section{Summary}

Background: The aim of this article was to evaluate the prognostic value of the MammaPrint ${ }^{\mathrm{TM}}$ signature in women $\geq 60$ years with invasive breast cancer. Patients and Methods: 60 female patients were included in this prospective study. Eligibility criteria included: pT1c-3, pN0-1a, grade 2/3, hormone receptor-positive and HER2negative tumor. The clinical risk was determined by Adjuvant! Online (AOL). Results: 38 patients (63\%) where considered to be low-risk patients by the 70-gene signature, while 22 (37\%) were considered to be high-risk patients. No statistically significant differences between low- and high-risk groups could be detected for conventional prognostic parameters, particularly not for Ki-67. By AOL, 33 patients (55\%) were considered to be at high risk, of which 20 had a discordant MammaPrint ${ }^{\mathrm{TM}}$ result. The discordance rate between the profile and AOL was $48 \%$, which is higher than in previous publications. When the 70-gene signature was used in combination with the clinical risk assessment, the recommendation for adjuvant systemic treatment differed in 11 patients $(18 \%)$. Conclusions: In the intermediate-risk subgroup, the 70-gene signature could be useful to decide in elderly patients whether they may benefit from adjuvant chemotherapy or not. Conventional clinicopathological factors were not suitable for a prediction of the 70-gene signature results in these patients.

\author{
Schlüsselwörter \\ Mammakarzinom - 70-Gen-Signatur · Postmenopausal . \\ Ältere Menschen · Prognosefaktor
}

\section{Zusammenfassung}

Hintergrund: Ziel dieser Arbeit war die Evaluierung der 70-Gen-Prognose-Signatur Mammaprint ${ }^{\mathrm{TM}}$ bei Patientinnen $\geq 60$ Jahre mit einem invasiven Mammakarzinom. Patienten und Methoden: 60 Patientinnen wurden für diese prospektive Studie rekrutiert. Einschlusskriterien waren: pT1c-3, pN0-1a, Grading 2/3, HormonrezeptorPositivität und HER2-negativer Tumor. Das klinische Risikoprofil wurde mit dem Programm Adjuvant! Online (AOL) eingeschätzt. Ergebnisse: 38 Frauen (63\%) wurden durch die 70-Gen-Signatur als Niedrigrisiko-Patienten eingestuft; demgegenüber stehen 22 (37\%) in der Hochrisiko-Gruppe. Beim Vergleich zwischen den Niedrigund Hochrisiko-Gruppen wurde kein statistisch signifikanter Unterschied für die konventionellen Prognoseparameter gefunden, insbesondere nicht für Ki-67. In der AOL-Analyse wurden 33 Patientinnen (55\%) als Hochrisiko-Patienten eingestuft, von denen 20 ein diskordantes 70-Gen-Signaturergebnis hatten. Eine Diskordanz zwischen der 70-Gen-Signatur und dem AOL-Ergebnis wurde bei $48 \%$ der Patientinnen ermittelt. Diese Rate liegt höher als in früheren Publikationen. Die Kombination von klinisch-pathologischer Risikoeinstufung und Gensignatur führte bei 11 Patientinnen (18\%) zu einer Änderung der adjuvanten systemischen Therapieempfehlung. Schlussfolgerungen: Die 70-Gen-Signatur könnte bei älteren Frauen mit einem mittleren Risiko ein Zusatzkriterium für bzw. gegen eine adjuvante Chemotherapieempfehlung sein. Die konventionellen klinischpathologischen Parameter korrelierten nicht mit der 70-Gen-Signatur für diese Patientinnen.

\section{KARGER \\ Fax +497614520714 \\ Information@Karger.de}

www.karger.com (c) 2012 S. Karger GmbH, Freiburg

$1661-3791 / 12 / 0071-0019 \$ 38.00 / 0$

Accessible online at:

www.karger.com/brc 


\section{Introduction}

The median age at diagnosis of breast cancer in North America and Europe is approximately 65 years [1]. The changing demographics of the population in developed countries and the increasing incidence of breast cancer with increasing age will lead to more cases of breast cancer in the older population [2]. The knowledge about possible differences in the biology and clinical outcome in these patients is limited because of their relative underenrollment in clinical trials [3, 4]. Making treatment decisions in elderly people is challenging. Many have comorbidities that may limit the life expectancy and may minimize or negate the benefits of adjuvant chemotherapy [1]. A clear recommendation to administer adjuvant chemotherapy to elderly breast cancer patients with node-positive, hormone receptor-negative tumors is given by the International Society of Geriatric Oncology. The benefit of adjuvant chemotherapy for hormone receptor-positive patients remains unclear [5].

Previously, van't Veer et al. [6] identified an optimal number of 70 marker genes that correctly predicted the later appearance or absence of metastases. Microarray data for older breast cancer patients are limited. 2 recent retrospective studies showed that the 70-gene analysis by the MammaPrint $^{\mathrm{TM}}$ assay (Agendia BV, Amsterdam, Netherlands) can also accurately predict the prognosis in older postmenopausal women $[7,8]$. The aim of our study was to prospectively identify subgroups in elderly women who show a poor 70-gene prognosis and may benefit from adjuvant chemotherapy or extended endocrine therapy when presenting with a hormone receptor-positive disease.

\section{Patients and Methods}

This prospective, bicentric observational study was approved by the ethics committee of the University of Rostock. All female patients who were diagnosed with primary invasive breast cancer by core-cut biopsy at 2 hospitals (University of Rostock and Oskar-Ziethen-Krankenhaus in Berlin) and who gave their informed consent and fulfilled the inclusion criteria (table 1), between July 2008 and December 2009, were included.

\section{Patients}

The patients were treated with breast-conserving surgery (BCS) or mastectomy and axillary sentinel lymph node biopsy (SLNB). In cases of an involved sentinel lymph node (SLN), axillary lymph node dissection (ALND) was conducted. Adjuvant systemic therapy and radiotherapy was recommended according to national guidelines, taking into account the patient's preferences and consent. Only 7 patients $(12 \%)$ received postoperative chemotherapy (table 2). All women were treated with an aromatase inhibitor or tamoxifen postoperatively or at the end of the chemotherapy. In cases with BCS, postoperative radiotherapy was mandatory. Patients with mastectomy were irradiated in case of node-positive disease.

\section{Gene Expression Analysis}

Immediately after the breast tumor was surgically removed, it was stored in a container without any preserving solution, taken to the pathology unit and processed by the attending local pathologist. Within $1 \mathrm{~h}$ after surgery, the pathologist took a tumor sample with a $3-\mathrm{mm}$ diameter biopsy punch and stored it directly after its removal in a container with RNARetain $^{\mathrm{TM}}$ solution ( $6 \mathrm{ml}$; Asuragen, Austin, TX, USA). On the same day, the samples were transported to the central Agendia Laboratories (Amsterdam, Netherlands). Quality tests of the RNA in each sample were done routinely at the Agendia Laboratories, where the prognosis signature test was undertaken as well. Neither the patients nor the local oncology team were informed about the result of the 70-gene signature. Therefore, the test result did not influence the recommendation of the multidisciplinary tumor board. To investigate the clinical relevance of the gene expression analysis, the tumor board made a second recommendation with the knowledge of the test results. This second decision had no impact on the therapy in practice.

\section{Clinical Risk Assessment}

To assess the 70-gene prognosis signature in a clinical context, it was compared with the clinico-pathological risk as predicted by Adjuvant! Online (AOL) version 8.0, available at www.adjuvantonline.com. AOL calculated the 10-year survival probability based on the patient's age, comorbidities, tumor size, tumor grade, estrogen receptor (ER) status and number of positive axillary lymph nodes $[10,11]$. Low clinical risk in ER-positive tumors was defined as patients with 10 -year breast cancerspecific survival (BCSS) as predicted by AOL at more than $92 \%$ [12].

Table 1. Defined inclusion and exclusion criteria of the presented prospective observational study

\begin{tabular}{ll}
\hline Inclusion criteria & histologically proven unilateral, invasive breast cancer \\
& patient's age at diagnosis $\geq 60$ years \\
& preoperative clinical N0 (cN0)/imaging N0 (iN0) \\
& postoperative pN0-1a $(0-3$ nodes positive) \\
& tumor size $>1 \mathrm{~cm}(\geq \mathrm{pT} 1 \mathrm{c})$ \\
& histological grading 2 or 3 \\
& hormone receptor-positive disease $(\mathrm{ER}>$ IRS 2 and/or PR $>$ IRS 2) \\
& HER2-negative tumor \\
& recurrent disease \\
& other malignant diagnosis during last 5 years \\
& primary metastatic disease $(\mathrm{M} 1)$ \\
Exclusion criteria & T4 disease \\
& preoperative systemic treatment \\
& male patients
\end{tabular}

ER = Estrogen receptor, $\mathrm{PR}=$ progesterone receptor, IRS = immunoreactive score [9],

HER2 = human epidermal growth factor receptor 2 by immunohistochemistry and/or chromogenic in situ hybridization. 
Table 2. Association between clinicopathological characteristics and 70-gene prognosis signature (all patients had HER2-negative breast carcinomas)

\begin{tabular}{|c|c|c|c|c|}
\hline Characteristics & $\begin{array}{l}\text { All patients, } \\
n=60 / 100 \%\end{array}$ & $\begin{array}{l}\text { Good prognosis signature, } \\
\mathrm{n}=38 / 63 \%\end{array}$ & $\begin{array}{l}\text { Poor prognosis signature, } \\
\mathrm{n}=22 / 37 \%\end{array}$ & $\mathrm{p}$ value \\
\hline Mean age, years & 70.3 & 69.2 & 72.2 & 0.11 \\
\hline Mean tumor size, $\mathrm{mm}(95 \% \mathrm{CI})$ & $20.1(18.4-21.8)$ & $20.2(17.8-22.5)$ & $19.9(17.2-22.6)$ & 0.76 \\
\hline Mean Ki-67 $(95 \%$ CI $)(n=53)$ & $15.9 \%(13.0-18.8)$ & $14.1 \%(12.0-16.1)$ & $19.0 \%(11.9-26.1)$ & 0.39 \\
\hline Tumor stage, $\mathrm{n}$ & & & & 0.26 \\
\hline pT1c & $33(55 \%)$ & $23(60.5 \%)$ & $10(45.5 \%)$ & \\
\hline pT2 & $27(45 \%)$ & $15(39.5 \%)$ & $12(54.5 \%)$ & \\
\hline pT3 & $0(0 \%)$ & $0(0 \%)$ & $0(0 \%)$ & \\
\hline Nodal stage, $\mathrm{n}$ & & & & 0.38 \\
\hline $\mathrm{pN} 0$ & $52(86.7 \%)$ & $34(89.5 \%)$ & $18(81.8 \%)$ & \\
\hline pN1mic & $1(1.7 \%)$ & $1(2.6 \%)$ & $0(0 \%)$ & \\
\hline $\mathrm{pN} 1 \mathrm{a}$ & $7(11.6 \%)$ & $3(7.9 \%)$ & $4(18.2 \%)$ & \\
\hline Histological tumor type, $\mathrm{n}(\mathrm{n}=58)$ & & & & 0.12 \\
\hline Ductal & $39(67.2 \%)$ & $23(63.9 \%)$ & $16(72.7 \%)$ & \\
\hline Lobular & $9(15.5 \%)$ & $4(11.1 \%)$ & $5(22.7 \%)$ & \\
\hline Other & $10(17.3 \%)$ & $9(25 \%)$ & $1(4.6 \%)$ & \\
\hline Histological grade, $\mathrm{n}$ & & & & 0.9 \\
\hline $\mathrm{G} 3$ & $3(5 \%)$ & $2(5.3 \%)$ & $1(4.5 \%)$ & \\
\hline Lymphovascular involvement, $\mathrm{n}$ & & & & 0.43 \\
\hline Yes & $18(30 \%)$ & $10(26.3 \%)$ & $8(36.4 \%)$ & \\
\hline No & $40(66.7 \%)$ & $26(68.4 \%)$ & $14(63.6 \%)$ & \\
\hline Unknown & $2(3.3 \%)$ & $2(5.3 \%)$ & $0(0 \%)$ & \\
\hline Surgical procedure, $\mathrm{n}$ & & & & 0.98 \\
\hline Breast-conserving surgery & $49(81.7 \%)$ & $31(81.6 \%)$ & $18(81.8 \%)$ & \\
\hline Mastectomy & $11(18.3 \%)$ & $7(18.4 \%)$ & $4(18.2 \%)$ & \\
\hline Adjuvant chemotherapy, $\mathrm{n}$ & & & & 0.36 \\
\hline No chemotherapy & $53(88.3 \%)$ & $34(89.4 \%)$ & $19(86.4 \%)$ & \\
\hline CMF-like & $1(1.7 \%)$ & $0(0 \%)$ & $1(4.5 \%)$ & \\
\hline AC-based & $2(3.3 \%)$ & $2(5.3 \%)$ & $0(0 \%)$ & \\
\hline Taxane + AC & $4(6.7 \%)$ & $2(5.3 \%)$ & $2(9.1 \%)$ & \\
\hline Upfront adjuvant endocrine therapy, $\mathrm{n}$ & & & & 0.11 \\
\hline Tamoxifen & $6(10 \%)$ & $2(5.3 \%)$ & $4(18.2 \%)$ & \\
\hline Aromatase inhibitor & $54(90 \%)$ & $36(94.7 \%)$ & $18(81.8 \%)$ & \\
\hline Adjuvant radiotherapy, $\mathrm{n}$ & & & & 0.46 \\
\hline Yes & $1(1.7 \%)$ & $0(0 \%)$ & $1(4.5 \%)$ & \\
\hline No & $59(98.3 \%)$ & $38(100 \%)$ & $21(95.5 \%)$ & \\
\hline
\end{tabular}

$\mathrm{CI}=$ Confidence interval; $\mathrm{CMF}=$ cyclophosphamide, methotrexate, and fluorouracil; $\mathrm{AC}=$ anthracycline.

Statistical Analyses

Calculations were done by use of SPSS (version 15.0; SPSS Inc., Chicago, IL, USA). Differences between the groups of interest were tested by the chi-square test for qualitative data and by the Mann-Whitney U-test for quantitative data (no normal distribution found by the K-S-Lilliefors test). A significant finding was defined as a $\mathrm{p}$ value lower than 0.05 as two-sided test.

\section{Results}

The 70-gene prognosis signature was assessed in tumor tissue of 65 breast cancer patients. 5 tumor samples $(8 \%)$ contained insufficient tumor cells; 60 samples (92\%) were hybridized successfully. Among these 60 patients, 38 (63\%) were classified as having a good prognosis signature, whereas 22 (37\%) were classified as having a poor prognosis signature. The median age for all patients was 69 years (range 60-87 years). There was no difference in tumor or patient characteristics between the good- and the poor-prognosis signature group with regard to age, tumor size, tumor stage, histological grade, histological tumor type, Ki-67, nodal or lymphovascular in- volvement. Surgical procedures and adjuvant treatment were similar in both groups (table 2). Furthermore, no correlation was found between the immunoreactive scores (IRS) for the $\mathrm{ER}$ and the progesterone receptor (PR) and the 70-gene signature results (table 3 ).

AOL classified 27 patients (45\%) as clinical low-risk and 33 patients $(55 \%)$ as clinical high-risk patients, using the predefined cut-off. This clinical risk assessment was discordant with the 70 -gene prognosis signature for 29 patients (48\%). 9 patients $(15 \%)$ were classified as clinical low-risk patients with poor-prognosis signature, 20 (33\%) were classified as clinical high-risk patients with good-prognosis signature (table 4).

Adjuvant chemotherapy was recommended in 7 of the 60 cases. The results of AOL and the 70-gene prognosis signature were discordant in 5 of these cases. 4 patients were considered to be 70-gene low-risk in spite of a high risk determined by AOL (1 patient with low-risk AOL and high-risk gene signature). The 2 patients with concordant results were high-risk patients for both AOL and the 70-gene signature (table 5). 


\begin{tabular}{|c|c|c|c|}
\hline IRS & $\begin{array}{l}\text { Good-prognosis signature, } \\
\mathrm{n}=34 / 63 \%\end{array}$ & $\begin{array}{l}\text { Poor-prognosis signature, } \\
n=20 / 37 \%\end{array}$ & $\mathrm{p}$ value \\
\hline $\begin{array}{r}\text { ER } \\
\\
0 \\
1 \\
2 \\
4 \\
6 \\
8 \\
9 \\
12\end{array}$ & $\begin{array}{r}0 \\
0 \\
0 \\
0 \\
9 \\
1 \\
10 \\
14\end{array}$ & $\begin{array}{r}0 \\
0 \\
0 \\
1 \\
1 \\
3 \\
3 \\
12\end{array}$ & . \\
\hline $\begin{array}{r}\text { PR } \\
0 \\
1 \\
2 \\
4 \\
6 \\
8 \\
9 \\
12\end{array}$ & $\begin{array}{r}0 \\
2 \\
0 \\
5 \\
10 \\
2 \\
7 \\
8\end{array}$ & $\begin{array}{l}0 \\
2 \\
3 \\
1 \\
2 \\
0 \\
4 \\
8\end{array}$ & 0.627 \\
\hline
\end{tabular}

Table 3. Association between IRS for hormone receptor status and 70 -gene prognosis-signature

Table 4. Comparison of risk assessment by AOL and 70-gene prognosis signature

\begin{tabular}{|c|c|c|c|}
\hline Clinical risk (AOL) & Good-prognosis signature, n (\%) & Poor-prognosis signature, $\mathrm{n}(\%)$ & Both, n (\%) \\
\hline Low risk & $18(30)$ & $9(15)$ & $27(45)$ \\
\hline High risk & $20(33)$ & $13(22)$ & $33(55)$ \\
\hline Both & $38(63)$ & $22(37)$ & $60(100)$ \\
\hline
\end{tabular}

Table 5. Risk assessment by AOL and 70-gene prognosis signature for patients with adjuvant chemotherapy recommendation

\begin{tabular}{llll}
\hline Clinical risk (AOL) & Good-prognosis signature, $\mathrm{n}$ & Poor-prognosis signature, $\mathrm{n}$ & Both, $\mathrm{n}$ \\
\hline Low risk & 0 & 1 & 1 \\
High risk & 4 & 2 & 6 \\
Both & 4 & 3 & 7 \\
\hline
\end{tabular}

Table 6. Risk assessment by AOL and 70-gene prognosis signature for patients without adjuvant chemotherapy recommendation

\begin{tabular}{llcl}
\hline Clinical risk (AOL) & Good-prognosis signature, $\mathrm{n}$ & Poor-prognosis signature, $\mathrm{n}$ & Both, $\mathrm{n}$ \\
\hline Low risk & 18 & 8 & 26 \\
High risk & 16 & 11 & 27 \\
Both & 34 & 19 & 53 \\
\hline
\end{tabular}

Standard adjuvant endocrine therapy for 5 years without adjuvant chemotherapy was recommended in 53 of the 60 cases. The results of AOL and the 70-gene prognosis signature were discordant in 24 of these cases (16 patients at low risk according to the 70-gene signature and at high risk besed on AOL, 8 patients at high risk according to the 70gene signature and at low risk based on AOL). Of the patients with concordant test results in this group, 18 were low-risk and 11 were high-risk patients in both investigations (table 6).

When the prognosis signature was used in combination with the clinico-pathological factors, the recommendation for adjuvant systemic treatment differed in 11 patients (18\%). Adjuvant chemotherapy would have been advised additionally in 6 patients $(10 \%)$ and withheld in 5 patients $(8 \%)$.

\section{Discussion}

Breast cancer is a common tumor in the elderly population and management of early disease in particular is a major chal- lenge for oncologists and geriatricians alike. Comorbidity in older patients may limit the ability to obtain prognostic information, tends to minimize treatment options and increases the risk of death from causes other than breast cancer. Chemotherapy has considerable effects on the quality of life of breast cancer patients [13]. Therefore, there is a current need for additional criteria for the selection of a postoperative systemic therapy for patients with intermediate-risk breast cancer, especially in the elderly.

The 70-gene prognosis signature has been prospectively validated as a prognostic tool for young women diagnosed with primary node-negative breast cancer [14]. Data regarding older breast cancer patients and the prognostic value of MammaPrint $^{\mathrm{TM}}$ are rare. 2 recent retrospective studies showed that the 70 -gene prognosis signature can predict prognosis also in older postmenopausal patients [7, 8]. There are no prospective data available for this large subgroup of patients. In contrast to the 2 retrospective investigations, we did not find any correlation between the 70-gene signature results and conventional prognostic parameters. 
Wittner et al. [8] reported an analysis of 100 patients with a median age of 62.5 years ( $n=69$ with an age $\geq 55$ years). 31 of all patients were younger than 55 years, not representing the 'elderly' population. High-risk breast carcinomas classified by the 70-gene signature were significantly related to tumors larger than $2 \mathrm{~cm}$, to higher histological grading, and to ERnegative disease ( $20 \%$ of all patients were ER negative). With $74 \%$ (51 of 69 ), the proportion of gene signature high-risk results for women $\geq 55$ years in this nodal-negative cohort was considerably high. In our opinion there is no benefit of the 70gene signature analysis for ER-negative patients, which is confirmed by Wittner et al. [8]. All 20 ER-negative breast carcinomas revealed a high-risk result.

Mook et al. [7] investigated a cohort of 148 postmenopausal patients aged 55-70 years with node-negative invasive breast cancer. Again, there was a significant association between high-risk gene signature results and tumor size greater than $2 \mathrm{~cm}$, higher histological grading, and ER-negative disease. Additionally, they describe significant differences between the 70 -gene signature low- $(61 \%)$ and high-risk (39\%) groups regarding tumor subtypes (more lobular and mixed tumors with low-risk signature). The Amsterdam group also included hormone receptor-negative tumors (22\% of all patients). Only $9 \%$ of all ER-negative tumors $(\mathrm{n}=32)$ showed a good-prognosis signature. On the other hand, only $5 \%$ of all grade I carcinomas $(n=55)$ revealed a poor-prognosis signature. These data support our study design with the exclusion of grade I (high probability for good prognosis) and ER-negative (high probability for poor prognosis) disease.

The lack of a correlation between conventional clinicopathological parameters and the 70-gene signature results in our study could be due to the strict selection criteria leading to a homogeneous study cohort. This clinically important subgroup representing the majority of elderly breast carcinoma patients is characterized by the luminal-subtype molecular classification pattern [15]. Our elderly study population is well characterized by ER/PR-positive, HER2-negative carcinomas with mainly moderate Ki-67 levels and grade II tumors (57 of 60). Among this subgroup, the 70-gene signature seems to be a helpful tool for the postoperative multidisciplinary tumor board.

In current practice, standard endocrine treatment of 5 years with an aromatase inhibitor or tamoxifen is usually recommended as systemic therapy alone for our study population. However, we identified $1 / 3$ of these older patients (37\%) to be high-risk patients by the 70 -gene prognosis signature. This fact leads to the question if these patients may benefit from an extended adjuvant therapy. Previous studies investigating younger cohorts found $49-73 \%$ of all patients to be at high risk $[6,12,14]$. This may reflect the differences in the biology of breast cancer in older women and the study cohort we have chosen (exclusively luminal-subtype tumors).
The proportion of patients with discordant clinical and 70gene signature risk $(48 \%)$ is larger than observed in prior validation series (29-38\%) [8, 14, 16]. These studies mainly tried to find patients with an adjuvant overtreatment with chemotherapy when classified clinically as high-risk patients but by MammaPrint $^{\mathrm{TM}}$ as low-risk patients. For our study cohort of elderly patients, we suppose the opposite, an adjuvant undertreatment, because more than $1 / 3$ of the patients were considered to be high-risk patients based on the 70-gene prognosis signature and only $12 \%$ were considered for adjuvant chemotherapy. Those high-risk patients benefit significantly from adjuvant chemotherapy for both BCSS and distant diseasefree survival [17].

Every 5th patient would have been recommended a different adjuvant systemic treatment with the knowledge of the 70gene prognosis signature. Therefore, in our opinion, this gene signature is a useful tool for a tailored adjuvant therapy in this selected intermediate-risk breast cancer subgroup.

To our knowledge, this is the first study evaluating the clinical relevance of the 70-gene prognostic signature in patients $\geq 60$ years in a prospective setting. Although we investigated a relatively small number of patients, a clear advantage of our investigation compared to previous studies is the homogeneous study cohort with the median age of 71 years. Considering the cost for gene signature assays, a selection of potential patients is necessary. Elderly women with ER-negative, HER2positive, and triple-negative breast carcinomas should be

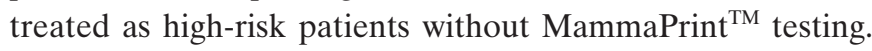
Furthermore, the 70-gene signature analysis seems not beneficial in elderly patients with grade I tumors. However, patients with 1-3 positive lymph nodes should be considered for 70gene analysis, because in postmenopausal patients the adjuvant treatment recommendation does not differ between $\mathrm{pN} 0$ and pN1a tumors [18].

In conclusion, our study indicates that application of the 70 -gene prognosis signature in breast cancer patients at 60 years of age or older could result in a more accurate allocation of adjuvant systemic therapy and has the potential to change treatment recommendations. No conventional clinico-pathological factor was suitable for prediction of the MammaPrint ${ }^{\mathrm{TM}}$ results. A poor prognosis signature would imply chemotherapy also for clinically low-risk patients. Recurrence-free and overall survival data after 2, 5 and 10 years of follow-up will reveal further information about the prognostic relevance of the 70-gene prognosis signature for our study cohort.

\section{Disclosure Statement}

Grant and equipment support: Agendia BV, Amsterdam, NL. Dagmar Doell (Agendia GmbH, Grafing, Germany) provided the Mammaprint ${ }^{\mathrm{TM}}$ kits and organized the logistic transfer of breast specimens. 


\section{Acknowledgements}

We would like to thank the doctors and nurses from the participating

hospitals, especially from the pathological units.

\section{References}

1 Muss HB, Biganzoli L, Sargent DJ, Aapro M: Adjuvant therapy in the elderly: Making the right decision. J Clin Oncol 2007;25:1870-1875.

2 Diab SG, Elledge RM, Clark GM: Tumor characteristics and clinical outcome of elderly women with breast cancer. J Natl Cancer Inst 2000;92:550556.

3 Hutchins LF, Unger JM, Crowley JJ, Coltman CA $\mathrm{Jr}$, Albain KS: Underrepresentation of patients 65 years of age or older in cancer-treatment trials. N Engl J Med 1999;341:2061-2067.

4 Townsley CA, Selby R, Siu LL: Systematic review of barriers to the recruitment of older patients with cancer onto clinical trials. J Clin Oncol 2005;23:3112-3124.

5 Wildiers H, Kunkler I, Biganzoli L, Fracheboud J, Vlastos J, Bernard-Marty C, Hurria A, Extermann M, Girre V, Brain E, Audisio RA, Bartelink H, Barton M, Giordano SH, Muss H, Aapro M: Management of breast cancer in elderly individuals: recommendation of the International Society of Geriatric Oncology. Lancet Oncol 2007; 8:1101-1115.

6 van't Veer LJ, Dai H, van de Vijver MJ, He YD, Hart AAM, Mao M, Peterse HL, van der Kooy K, Marton MJ, Witteveen AT, Schreiber GJ, Kerkhoven RM, Roberts C, Linsley PS, Bernards R, Friend SH: Gene expression profiling predicts clinical outcome of breast cancer patients. Nature 2002;415:530-536.

7 Mook S, Schmidt MK, Weigelt B, Kreike B Eekhout I, van de Vijver MJ, Glas AM, Floore A, Rutgers EJT, van't Veer LJ: The 70-gene prognosis signature predicts early metastasis in breast cancer patients between 55 and 70 years of age. Ann Oncol 2010;21:717-722.
8 Wittner BS, Sgroi DC, Ryan PD, Bruinsma TJ, Glas AM, Male A, Dahiya S, Habin K, Bernards R, Haber DA, van't Veer LJ, Ramaswamy S: Analysis of the MammaPrint breast cancer assay in a predominantly postmenopausal cohort. Clin Cancer Res 2008;14:2988-2993.

$\checkmark 9$ Remmele W, Stegner HE: Recommendation for uniform definition of an immunoreactive score (IRS) for immunohistochemical estrogen receptor detection (ER-ICA) in breast cancer tissue. Pathologe 1987;8:138-140.

10 Olivotto IA, Bajdik CD, Ravdin PM, Speers CH, Coldman AJ, Norris BD, Davis GJ, Chia SK, Gelmon KA: Population based validation of the prognostic model ADJUVANT! for early breast cancer. J Clin Oncol 2005;23:2716-2725.

11 Ravdin PM, Siminoff LA, Davis GJ, Mercer MB, Hewlett J, Gerson N, Parker HL: Computer program to assist in making decisions about adjuvant therapy for women with early breast cancer. J Clin Oncol 2001;19:980-991.

12 Buyse M, Loi S, van't Veer L, Viale G, Delorenzi M, Glas AM, d'Assignies MS, Bergh J, Lidereau R, Ellis P, Harris A, Bogaerts J, Therasse P, Floore A, Amakrane M, Piette F, Rutgers E, Sotiriou C, Cardoso F, Piccart MJ: Validation and clinical utility of a 70-gene prognostic signature for women with node-negative breast cancer. J Natl Cancer Inst 2006;98:1183-1192.

13 Reimer T, Gerber B: Quality-of-life considerations in the treatment of early-stage breast cancer in the elderly. Drugs Aging 2010;27:791-800.
Bueno-de-Mesquita JM, van Harten WH, Retel VP, van't Veer LJ, van Dam F, Karsenberg K, Douma K, van Tinteren $\mathrm{H}$, Peterse JL, Wesseling J, Wu TS, Atsma D, Rutgers E, Brink G, Floore AN, Glas AM, Roumen R, Bellot FE, van Krimpen C, Rodenhuis S, van de Vijver MJ, Linn SC: Use of 70-gene signature to predict prognosis of patients with node-negative breast cancer: a prospective community-based feasibility study (RASTER). Lancet Oncol 2007;8:1079-1087.

15 Sørlie T, Perou CM, Tibshirani R, Aas T, Geisler S, Johnsen $H$, Hastie $T$, Eisen MB, van de Rijn M, Jeffrey SS, Thorsen T, Quist H, Matese JC, Brown PO, Botstein D, Lonning PE, Borresen-Dale AL: Gene expression patterns of breast carcinomas distinguish tumor subclasses with clinical implications. Proc Natl Acad Sci USA 2001;98:10869-10874.

16 Mook S, Schmidt MK, Viale G, Pruneri G, Eekhout I, Floore A, Glas AM, Bogaerts J, Cardoso F, Piccart-Gebhart MJ, Rutgers ET, van't Veer LJ: The 70-gene prognosis-signature predicts outcome in breast cancer patients with 1-3 positive lymph nodes in an independent validation study. Breast Cancer Res Treat 2009;116:295-302.

17 Knauer M, Mook S, Rutgers EJT, Bender RA, Hauptmann M, van de Vijver MJ, Koornstra RHT, Bueno-de-Mesquita JM, Linn SC, van't Veer LJ: The predictive value of the 70-gene signature for adjuvant chemotherapy in early breast cancer. Breast Cancer Res Treat 2010;120: 655-661.

18 Goldhirsch A, Glick JH, Gelber RD, Coates AS, Thürlimann B, Senn HJ: Meeting Highlights: International expert consensus on the primary therapy of early breast cancer 2005. Ann Oncol 2005;16:1569-1583. 